\title{
An early Canadian-made chloroform inhaler
}

\author{
Daniel Chartrand, MD, PhD, FRCPC (B)
}

Received: 10 October 2017/Accepted: 17 October 2017/Published online: 1 November 2017

(C) Canadian Anesthesiologists' Society 2017

On January 21, 1848, in Quebec City, Dr. James Sewell performed the first operation under chloroform anesthesia reported in Canada. ${ }^{1}$ With his colleagues, Drs. William Marsden and James Douglas, he performed and subsequently reported several other operations under chloroform anesthesia. On February 15, 1848, use of the first anesthesia inhaler was described by Dr. Marsden, ${ }^{2}$ who noted that

“... a piece of lint having been placed in a funnelshaped piece of sheet lead, open at both ends, about a drachm and a half $(5.3 \mathrm{~mL})$ of chloroform was poured upon the lint, and then applied to the mouth and nose

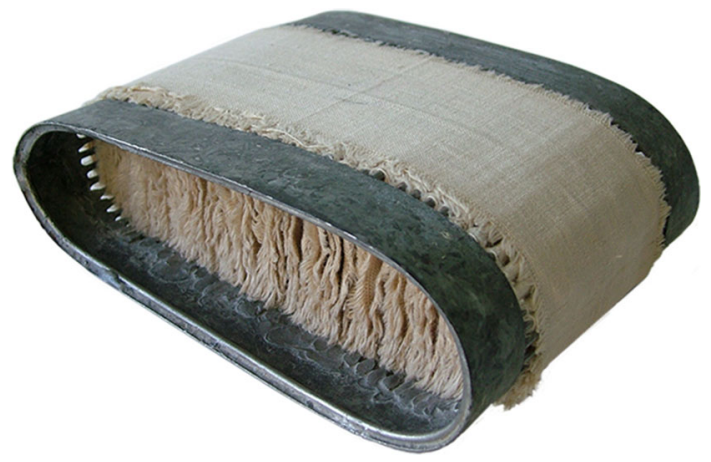

Figure Chloroform inhaler built by the Augustine nuns in 1848 at Dr. Marsden's request. It can be found in the "Hôtel-Dieu de Québec" collections of the Musée du Monastère des Augustines, Quebec City. Reproduction of the photograph was done with the permission of the Museum of the Augustines' Monastery

D. Chartrand, MD, PhD, FRCPC ( $\square)$

Department of Anesthesia, Montreal Neurological Hospital (MUHC), Montreal, QC, Canada

e-mail: Daniel.Chartrand@McGill.ca of the patient, to be inhaled or inspired.... The breathing of the patient became somewhat laborious and quick soon after applying the chloroform, which was probably occasioned by the outer aperture of the leaden funnel being rather small...."

Not satisfied with the performance of that first funnelshaped inhaler, or with a second one ordered from Scotland, Dr. Marsden asked the Augustine nuns of the Hôtel-Dieu de Québec, the oldest hospital in North America, ${ }^{3}$ to build a better one. Using their ingenuity and skills, the Augustines handcrafted what is likely the first Canadian-designed and Canadian-constructed chloroform anesthetic apparatus (Figure). It can still be seen in the Museum of the Augustines' Monastery in Quebec City. ${ }^{\text {A }}$

Conflicts of interest None declared.

Editorial responsibility This submission was handled by Dr. Hilary P. Grocott, Editor-in-Chief, Canadian Journal of Anesthesia.

\section{References}

1. Martin J. Chloroform at the Marine hospital. The British American Journal of Medical and Physical Science 1848; 3: 325-6.

2. Marsden W. Chloroform in Quebec. The British American Journal of Medical and Physical Science 1848; 3: 288-9.

3. Jacques A. $325^{\text {th }}$ Anniversary: anesthesia, past \& present. Anesth Analg 1966; 45: 15-20.

\footnotetext{
A Musée du Monastére des Augustines (Museum of the Augustines' Monastery), 77, rue des Remparts, Québec (Québec) G1R 0C3; (418) 694-1639 / 1 (844) 694-1639.
} 